\title{
Dichotomy of Family Relations of Azerbaijani Society in the Process of Globalization
}

\author{
Yagut Nadir Aliyeva
}

$\mathrm{PhD}$ in Sociology, Assistant Professor, Baku State University, Baku, Azerbaijan

\section{Sevinj Nadir Aliyeva}

$\mathrm{PhD}$ in Sociology, Lecturer, Baku State University, Baku, Azerbaijan

\section{Mykola Zhurba}

$\mathrm{PhD}$, Professor, Department of Educational Management, Lugansk Regional Institute of Postgraduate Pedagogical Education, Severodonetsk, Ukraine

\begin{abstract}
This article examines the issues related to the fundamental social changes that are taking place in all countries with a transition economy. It is noted that against the background of globalization of the world, a systemic transformation of modern Azerbaijani society takes place, which influences the formation of new family relations in the country. Tracing the main trends in the formation of new family relations in Azerbai$\mathrm{jan}$ in the context of the formation of civil society, contradictions and difficulties in this area and indicating ways to overcome them is of urgent importance both in scientific and theoretical/philosophical and sociological, philosophical, and socially practical terms.
\end{abstract}

Keywords: social structure, family, family relations, transformation, globalization.

JEL Classification: F60.

(C) The Authors, 2017. This article is published with open access at ARMG Publishing.

\section{Introduction}

At present, fundamental social changes occur in the Azerbaijani society, characteristic of all countries with a transitional economy. Against the backdrop of the globalization of the world, a systemic transformation of modern Azerbaijani society takes place, influencing the formation of new family relations in the country.

These trends are already manifested in the social reality of Azerbaijani society through the dichotomy of the goals and means that have developed in society, the contradictions in changes in the forms of ownership, the emergence of a new system of social relations, the need to reassess traditional spiritual values, as well as the relation between traditionalism and modernism on the family, substantial, structural and functional changes in family-marriage relations, the paradoxes of necessity and expediency in the upbringing of children. Hence, the peculiarities of the tendencies in the formation of new family relations in Azerbaijan depend on the objective conditions of the social environment - the transformational society and the subjective situations arising because of these changes $(1,2,8,13)$.

The urgency of philosophical and sociological study of this topic is also dictated by the fact that the process of social restructuring in Azerbaijan is at the stage of formation, and a theoretical analysis of this process would greatly contribute to its optimization and optimization in the field of family problems.

Obviously, many issues that directly relate to the problems of the family have ripened, from the effective and immediate solution of which the overcoming of socio-economic, political, spiritual and other contradictions in society also largely depends.

The theoretical relevance of the study of the Azerbaijani family in modern conditions also stipulates the consideration, within the framework of the traditional surname concept, of the peculiarities of changing family relations and family upbringing. Since the Azerbaijani family differs in many respects from the family of other nations, even the people professing the Islamic religion, it is necessary to consider the fact that without considering the mental, national-ethnic, socio-psychological characteristics of Azerbaijanis, it is impossible to give an adequate description of the Azerbaijani family and predict its possible changes. 


\section{Literature review}

The review and analysis of literature in the field of studying the problems of the family and society shows that this problem belongs to the category of complex and multidimensional phenomena at the intersection of various sciences: sociological, philosophical, psychological, pedagogical, socio-psychological, cultural, demographic, etc., each of which has its own ideas and approaches.

Since family problems have always been in the center of attention of scientists, the range of points of view on the genesis, state and perspective of the institution of the family is diverse and contradictory. The scientific study of the family and marriage attracts a great deal of interest. Ancient thinkers wrote about the family, considered it only as an element of broader social structures and the forerunner of more complex forms of social organization.

Systematic scientific study of the family as a social phenomenon began with the study of primitive forms of marriage, which is associated with the names of Bachofen, I., McLennan, J., Lebbock, J., L. G. Morgan, Lippert, E. Wester-Mark (evolutionary and functional approach), Leturno, Murdoch, J., Ogborn, U., Burgess, E., Locke, H. (functional approach), Kovalevsky, M., Sternberg, Marx, K. Engels, F. and other scientists. In many countries sociological studies of the family are particularly active. The main attention is paid to such problems as relations between family members as individuals, the economic basis of the family, family order, the division of roles and forms of authority, intergenerational relations, the problems of an incomplete family, the new role and position of women. An important role in the study of family problems is played by such aspects as the types of social relations characteristic of the family, its relationship with other areas of social life, as well as analysis of the characteristics of the family and its social functions. In the USSR, the sociological research of the family has been particularly active since the mid-1960s. By the mid-1990s, two concepts of the modern family were clearly formed: alarmist (defended by demographers, based on the idea of losing the most important values that cemented the family) and liberal (protected by sociologists and economists, based on the idea of progress and the exaltation of the value of free choice). Obviously, in fact, here we are talking about the opposite assessments of the process of modernization of the family - the family of the so-called transition period. To a certain extent, the autonomous niche in the analysis of family relations and gender identity is formed by those representatives of scientific and humanitarian thought, which in fact develop a culturological approach.

The family, being an evolutionary invention of humanity, is constantly changing, and the personalityfamily-society relations also change. In this regard, studies of the family and these changes were conducted on the basis of various approaches and directions: interaction (interaction of family members); institutional (analysis of family-marriage relations); structural-functional (family analysis as a system); evolutionary (unified approach system); situational (family values).

In Azerbaijan, to a certain extent, family problems were investigated in the works of Aliyeva, Ya.N, Aliyev, A., Aliyev, R.Ya., Sadykov, A.I. (family-marriage relations, culture, spiritual values, interethnic marriages), Kuliyeva, N. M. (life of modern rural families), Alizadeh, F. (educational and demographic problems of the family), Geybullaev, G.A. (questions of endogamy, historical and ethnographic research and modern life of Azerbaijani families), Kuliyev, G.A. (life and family relations), Badalov, R. and Mirzoev, N.Sh. (family functions), Akhundov, S. and Hasanov, A. (morality the education of children), Abbasov, A. and Babayev, N. (mother-woman problems), Rallahverdiyev, I. (socio-psychological analysis of marital conflicts), Akhmedov, A., Eminov, A., Mamedov, A., Gavilov, G.A. (about wedding customs and traditions, about Islamic morals and values $[1 ; 2 ; 3 ; 6 ; 7 ; 8 ; 13]$.

Meanwhile, the growing relevance of issues related to the trends of changes in the social structure of Azerbaijani society, indicates that social development is confronted with new processes that create certain difficulties in politics, economy, culture, ideology, family relations, upbringing, etc. This problem has broad outlets in social practice, as evidenced by works on the sociology of family and marriage, social structure, education problems, sociology of culture, economic sociology, sociology of politics, sociology of youth, religion, etc.

The research is aimed at revealing the features of the historical development of society, the emergence of new social relations in the process of social evolution, the dynamics of changes in ownership patterns / positive and negative points, the need to reassess traditional spiritual values. At the same time, interest is growing in the study of historical types and forms of marriage and family relations, trends and prospects for their 
development, revealing the dialectics of the general, the and the individual in the activity of the family at each stage of its history, and through them the wider social structures and patterns are studied. Hence, one can conclude that the problems of society and the family are interdependent and are investigated together. Analysis of the situation of the modern Azerbaijani family makes it possible to determine characteristics characterizing it considering the influence of the assimilating factors that take place.

Nevertheless, it should be noted that in the modern domestic sociology there are practically no conceptual works devoted to the study of trends in the social structure of the Azerbaijani society and their reflection on family relations. To a certain extent, the problem of substantive, structural and functional changes in the social structure of Azerbaijan was studied in the works of Azerbaijani scientists: Ahmedli, J.T., Imanov, G.R., Rahimov, A.A., Ismailov, E.R., Abbasov, A.F., Askerov, I.S., Gasanov, R.M., Agayev, T.B., Khudiev, R.N., Hanlarov, A.S., Gasanov, G.A., Bayramov, G., Mamedov, R.O. Aliev, Ya.N. etc. In their works the main attention was paid to the study of the main trends of structural changes. In our work, an attempt is made to trace the channels of reflection of these changes on family relations $[2 ; 4 ; 5 ; 9 ; 12]$.

For a more complete analysis of the social structure of a transforming society, let us pay attention to the fact that from the 90s to the 2010s, social stratification of Azerbaijani society was characterized in general by two features: dynamism and incompleteness. At the same time, the stratification of Azerbaijani society at the present stage of development in the process of globalization is determined by three groups of criteria: political, economic and socio-cultural. However, such criteria as income, occupation and position, usual for Western countries, according to the specifics of the social structure of Azerbaijani society, do not always reflect the objective picture of stratification, as evidenced by the results of our studies.

\section{Socio-structural changes in Azerbaijan}

The processes of transformation that take place in Azerbaijani society cannot but affect both the system of values of society and the institution of the family. The process of transformation and globalization in Azerbaijan is accompanied by significant changes in social relations, which is explained by the breaking of old and gradual formation of new property relations. In turn, this process necessitates a reassessment of traditional values, which include norms and stereotypes of trends in the changing social structure of society and their reflection on family relations.

The main points of socio-structural changes in Azerbaijan are:

$>$ due to the denationalization of property, various types and forms of ownership appear: public, private, mixed and personal;

$>$ since many forms of ownership, a new system of social relations appears: property relations, labor, distribution, exchange, etc.;

$>$ new political, legal, moral, religious and other relations are being built on these forms of economic relations;

$>$ because of sharp socio-economic polarization and segmentation, a certain part of society is thrown out of the poverty line and forms the basis of exploited class, and at the same time new classes (layers) of society emerge;

$>$ there is a rapid process of revaluation of values, and traditional value criteria are sometimes replaced by opposite.

To eliminate the negative consequences of the transition to a market economy and the process of globalization, it is necessary to accelerate the implementation of structural reforms in management and return science and education to a priority role in society.

On the materials of the conducted research, we tried to identify positive and negative trends in family life and relations, caused by the transition of society to market relations and the process of globalization. The study and study of this problem is necessary for predicting changes in the family, identifying the main trends in the formation of new family relations in the conditions of the formation of civil society. When studying the problems of the family, special emphasis is placed on studying the instability of marriage, the causes, motives and consequences of divorces, and other negative and destabilizing factors and phenomena in this area.

The analysis of the significance of various aspects of human life, in determining their role in assessing the family and family relations is of interest.

The results of the study (2000-2003) revealed the following picture: good health (76.4\%); mutual understanding in the family with children, parents, spouses (35.0\%); obtaining a good education (18.8\%); a suc- 
cessful marriage (22.2\%); material welfare $(23.4 \%)$; interesting work (32.8\%); a prestigious position in society $(46.6 \%)$. Today, these figures have not changed much.

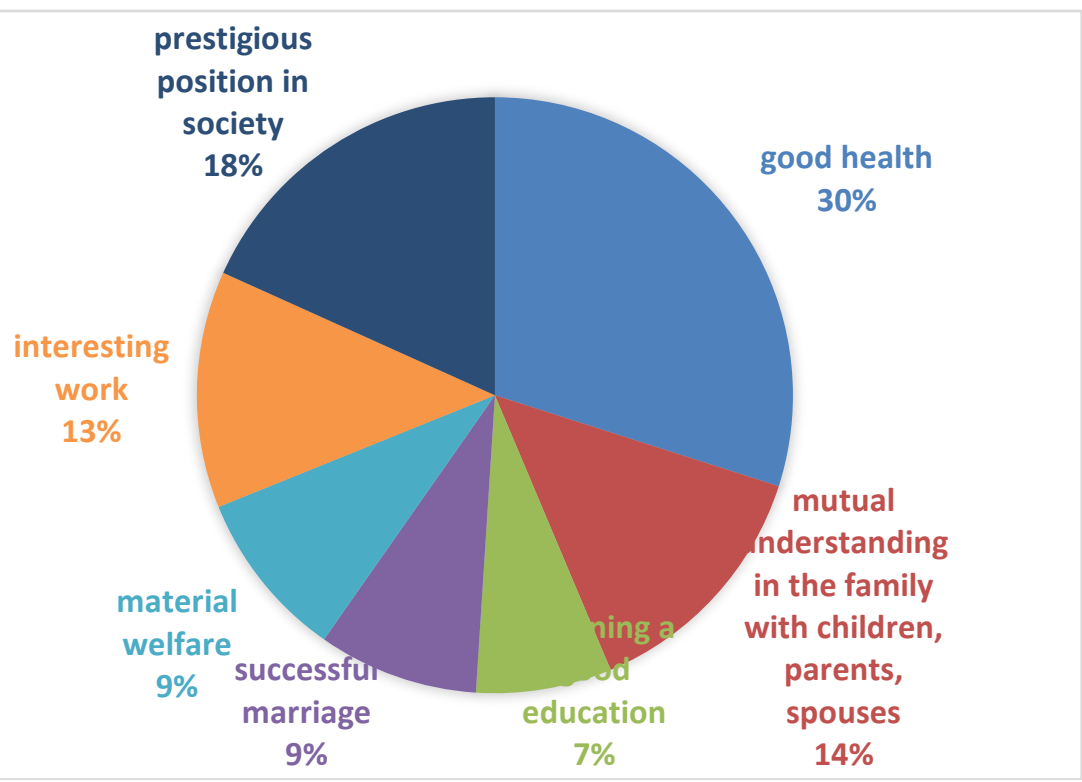

Figure 1. The significance of various aspects of human life (2000-2003)

An important role in the study of family problems is the relationship in the family. So, among the respondents who were married, they are satisfied with marital relations $-24.6 \%$, i.e. $1 / 2$ respondents were satisfied to a certain extent $-17.6 \%$, rather dissatisfied $-3.8 \%$ and unsatisfied $-1.2 \%$ of respondents.

In a two-stage study, the answers of the spouses to the question: How did interpersonal relationships in your family change under the current conditions? - were distributed as follows: $25 \%$ - family relationships did not change, 5\% - changed for the better, $45 \%$ - changed for the worse, and $25 \%$ - found it difficult to answer (2000-2003). Today, these figures look slightly different, to be more precise: $20 \%$ - family relations have not changed, $25 \%$ - changed for the better, $25 \%$ - changed for the worse, and 30\% - it was difficult to answer (2013-2017).

In 2000-2003

$$
\begin{aligned}
& \text { family relationships did not change } \\
& \text { changed for the worse }
\end{aligned}
$$

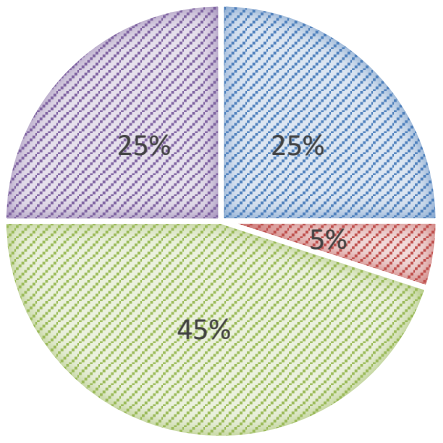

In 2013-2017 


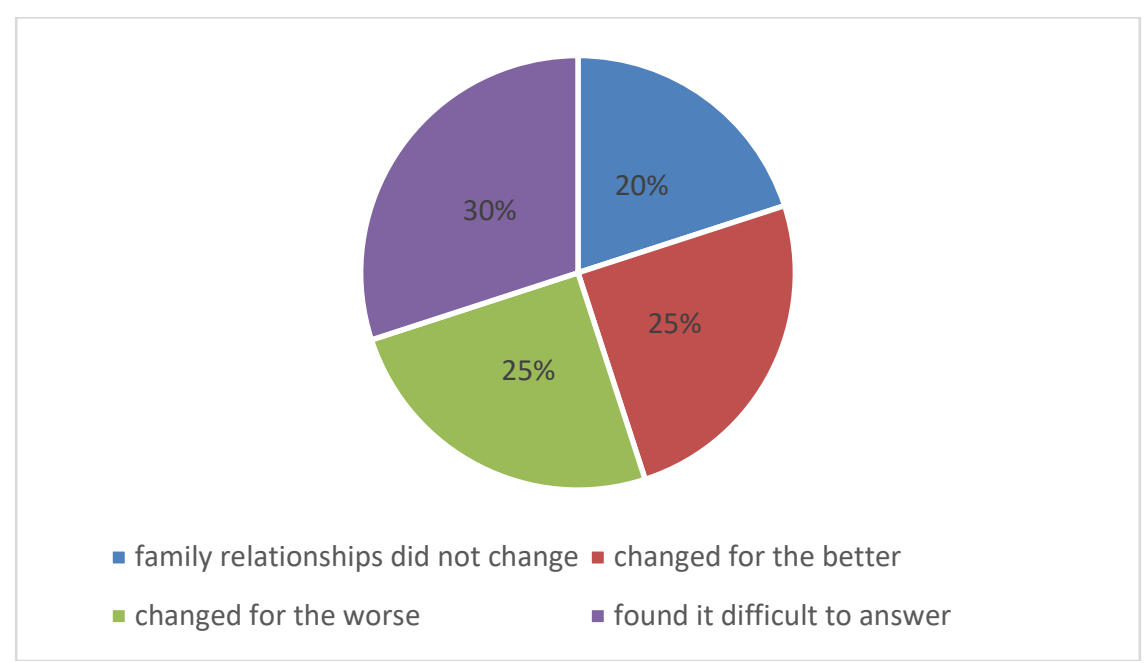

Figure 2. How did interpersonal relationships in your family change under the current conditions?

Attention should be paid to the fact that the development of the functions, structure and role behavior of the family was greatly influenced by the fact that the woman turned into an active member of society. Elimination of socio-economic differences in the position of men and women has created diverse opportunities for the upbringing of children, socio-political activity, study, recreation, familiarizing with the values of culture, fulfilling the socially significant role: the teacher of children and the hostess of the house.

The results of sociological surveys (1998-2003), conducted by us, also showed that $1 / 2$ of the respondents of married people were satisfied with family relations to a certain extent and $10 \%$ were not satisfied. The main reasons for the destabilization of marriage respondents indicated: the nature of the spouse $-18 \%$; lack of money $-18 \%$; accumulated problems $-17.6 \%$; own character $-13.2 \%$; household dislocation $-11.8 \%$; the upbringing of children $-4.8 \%$. In general, these figures have not changed much today.

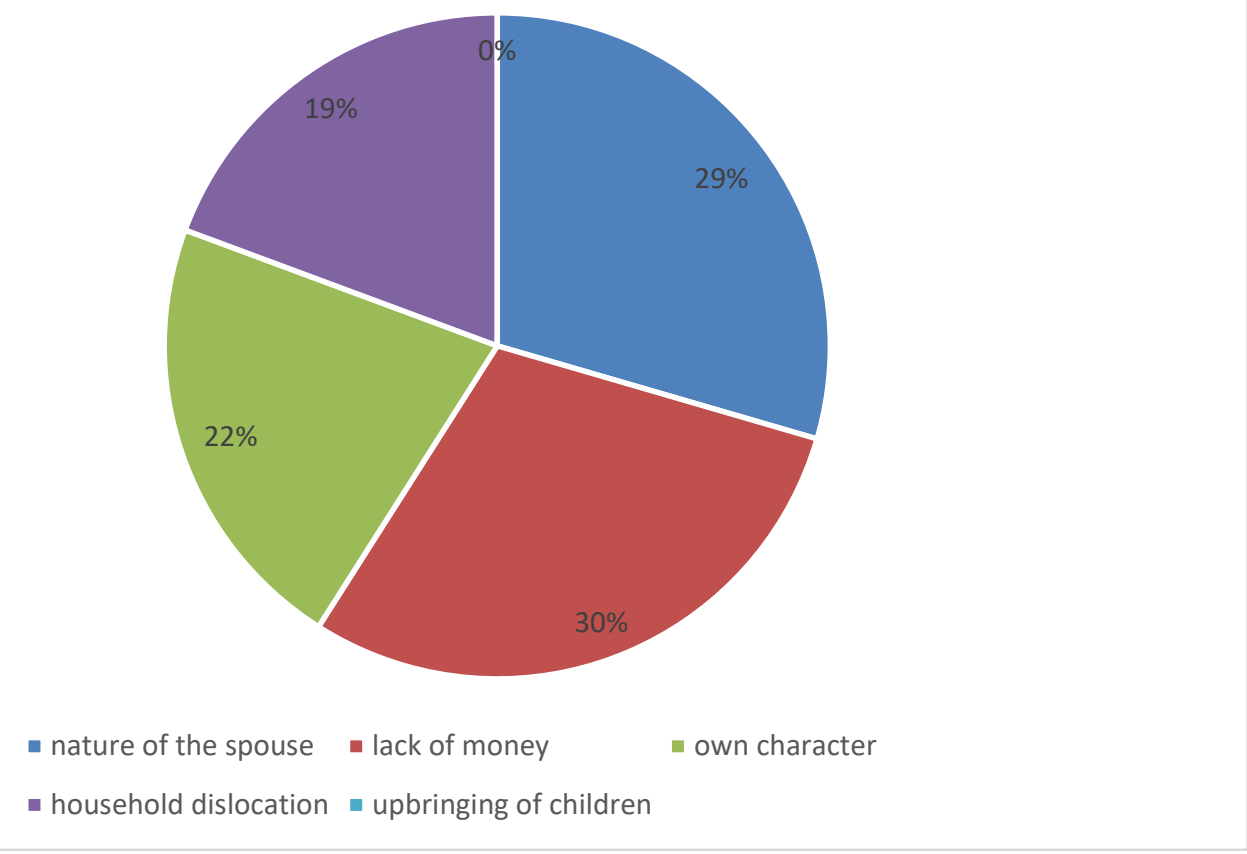

Figure 3. The main reasons for the marriage destabilization

Official data of the State Statistics of the country for 2000-2001 show that 13.4\% of marriages for one reason or another disintegrate in the first year of marriage, and this trend persists, and sometimes it increases to the present. Although this indicator for the US, Western countries, and even Russia is insignificant, for our country it is very significant. Analyzing conjugal relationships based on the results of the study, one can conclude that the main reasons for any level of divorce and conflict in young families lie in the socioeconomic, moral and psychological climate, in the absence of normal living conditions, in the intervention of 
the elderly newlyweds, in the absence of the relationship of the spouses, in their inability to rationally manage the household.

When analyzing and revealing the family's difficulties in modern conditions, the respondents point out the problems associated with the organization of everyday life and leisure. It is noted that a significant feature of the change in family life is the redistribution of duties of spouses in the home, which is particularly indicative in Azerbaijani families, where quite recently there was a completely different family-household structure and homework was exclusively a woman's duty. Answering the question: "Does your family have a redistribution of duties of spouses in the home?" - about half of the interviewed spouses answered in the affirmative, i.e. 21.6\% - "yes", 7.8\% - "no", 7.4\% - "I cannot answer" (2000-2003). Today there is a tendency to increase affirmative answers regarding this issue.

\section{Does your family have a redistribution of duties at home? (2000-2003)}

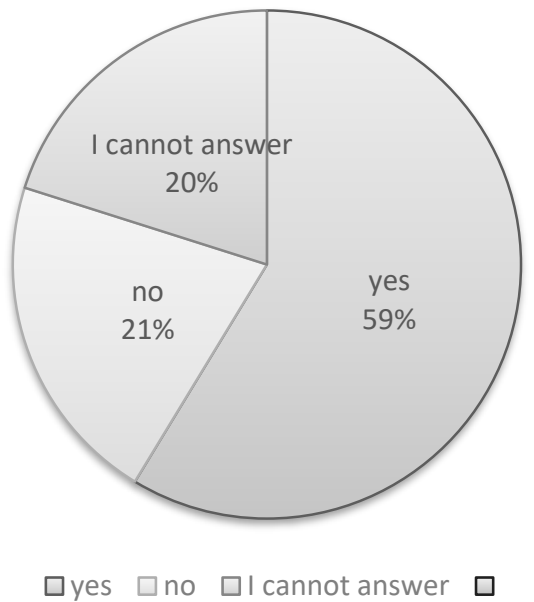

Modern men are increasingly persuaded that caring for the family, children cannot boil down to one-time, episodic facts of helping their wife, but is their constant duty, conscience and matrimonial duty. To the question: "How would you like to share the duties of spouses at home?" $-48.0 \%$ of respondents are for joint work at home; $26.6 \%$ believe that men should help in everything; $16.0 \%$ - everyone should have his own duties; $9.3 \%$ - the wife should conduct housekeeping, and the husband should buy the products, the parents should take care of the children equally.

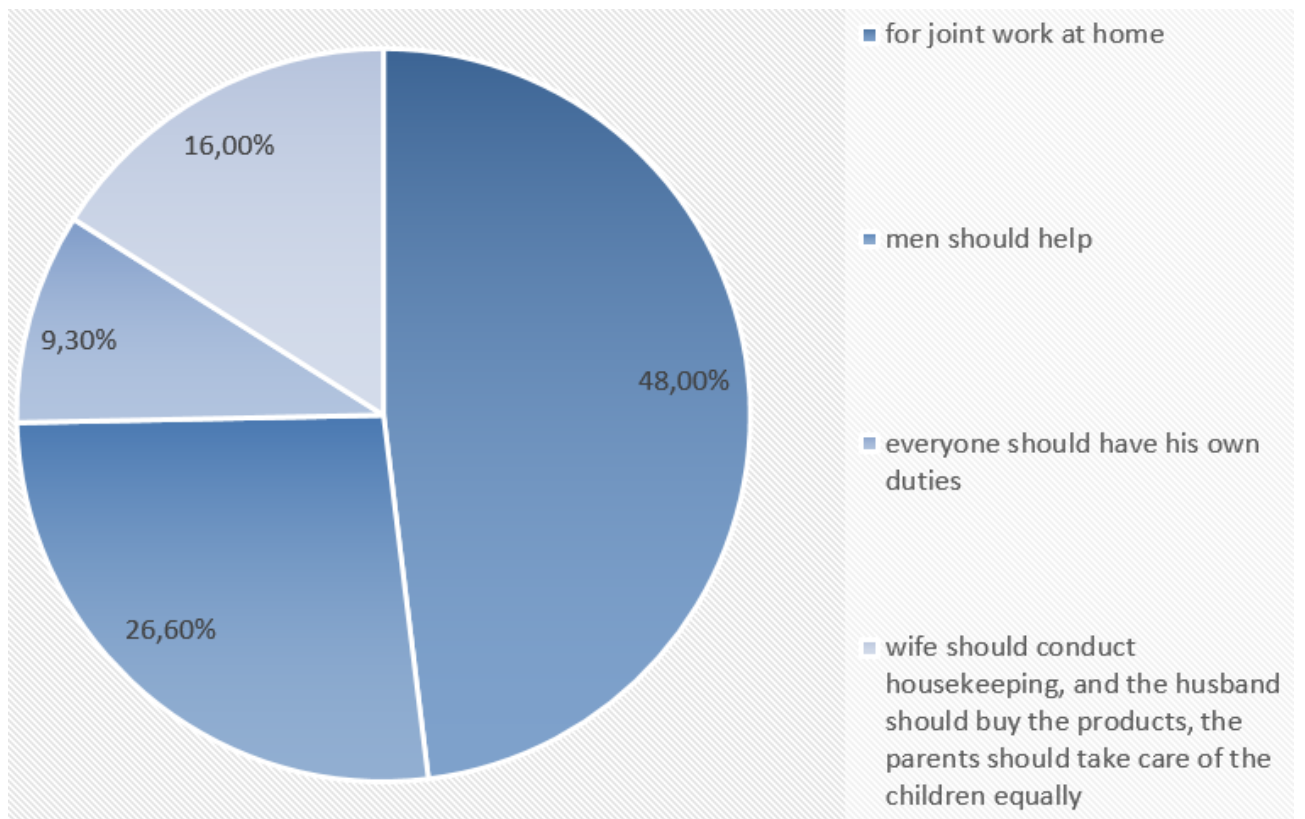


Hence, the important aspect of the life of the working (or for some reason or other not working) spouses is their everyday activities, the improvement of their functions relates to the radical changes that have taken place in the way of life of the modern family. The most important changes in this area are the reduction of time and labor costs for housekeeping and the expansion of everyday cultural life. At the same time, family relations are positively influenced by a favorable psychological situation in the family, enabling each of its members to do what they love, relax and share leisure time. In addition, leisure communication of spouses is a serious evidence of their social equality in the family. In general, these indicators, according to the results of the study, are low - less than $50.0 \%$, namely: $47.2 \%$ of respondents discuss the economic affairs of the family; $42.9 \%$ - education; $36.7 \%$ - plans for free time; $22.8 \%$ - questions of professional activity (20002003, 2013-2017)

Apparently, in modern conditions in Azerbaijan, the economic independence of a woman does not reduce the enormous value of family life for her. According to the results of the survey, about half of the respondents - married women (28.4\%) prefer family life to professional work, slightly more than $1 / 5$ - on the contrary, they place their careers above their families. $21.4 \%$ of respondents consider family life and professional work to be equally important aspects of their life, however, before choosing one of these two aspects, $2 / 3$ - family life would prefer a career. Only those ( $1 / 3$ of respondents) who are engaged in creative activity, in the absolute majority in general would not give up professional work. They also believe that, whenever possible, it is necessary to find a compromise in this situation to avoid problems in the family (2000-2003, 2013-2017).

In this aspect, survey results also show that 65\% (2013-2017) and 75\% (2000-2003) of men interviewed against the career growth of their wives. They believe that the wife in the first place should be the mistress of the house, and all other social roles of the woman should remain in the background. Only $15 \%$ in 2000 2003 and $25 \%$ in 2013-2017, men believe that it is necessary to give the opportunity to their wives to make a career, if it is very important for them, especially if they are engaged in creative activity. Nevertheless, they believe that the wife should not forget about domestic duties $[1 ; 2 ; 3 ; 7 ; 8 ; 10 ; 13]$.

Alternatives to a legitimate traditional family, such as civil marriages, same-sex quasi-families and others, that are negatively perceived by the Azerbaijani society deserve special interest and attention. The inadequacy of the process of transition from the traditional to the modern type of family negatively affects the combination of professional and family functions by the woman, generates specific conflicts between husband and wife, affects the satisfaction of family life and the stability of marriage. Under these conditions, considering the characteristics of existing family types, specific interests of spouses, differentiated assistance to different categories of families is an important factor in increasing the effectiveness of social policy in the family.

\section{Conclusions}

In real life, the process of transition from the traditional to the egalitarian type of the Azerbaijani family is far from complete. Currently, there are different models of the relationship between husband and wife, parents and children. With a general orientation toward combining professional and family roles, there are (and probably will always exist) categories of women with different hierarchies of values in the family and work. There are also significant discrepancies between the attitudes of the spouses on their role in the life of the family and the way these settings are put into practice.

Socially, these changes are expressed in the nuclearization of families, the preference for career achievements in the role of women, mothers, the increase in the number of divorces, single mothers, little children and childlessness, and consequently, depopulation, loneliness as a social problem, the fragility of families, diminishing the prestige of the family and the status of housewife. Thus, summarizing the results of our study, we can distinguish the following trends in the changes taking place in the sphere of family-marriage relations: from the "communal family" to the individual; from a large family to a child with few children; from full family to incomplete; from "legal" family to "illegal"; from the "traditional" extended family to the modern nuclear (modern) family, that is, from the "big" family to the "local" family.

\section{References}

1. Agayev, T. B. (2015). Stratification processes in modern Azerbaijan society. VII Republican ScientificPractical Conference on "Education Development Strategy and its Realization" dedicated to the 92nd anniversary of national leader Heydar Aliyev, May 7, 2015, Baku, p. 82-88. 
2. Akhmedli, J. T. (1988). Aktivizatsiya chelovecheskogo faktora i problemy sovershenstvovaniya raspredelitel'nykh otnosheniy. Tematicheskiy sbornik [The activation of the human factor and the problem of improving distributive relations. Thematic collection]. Baku.

3. Aliev R. Ya. (2006). Semeyno-brachnyye otnosheniya v islame. Per. s azerb. s dop. Baku [Familymarriage relations in Islam. Transl. with Azerbaijan. with add.].

4. Alieva Y. N. (2010). Formirovaniye novykh semeynykh otnosheniy v Azerbaydzhane v usloviyakh transformatsii obshchestva (genderno-sotsiologicheskiy analiz) [Formation of new family relations in Azerbaijan in conditions of society transformation (gender-sociological analysis)]. Aktual'nyye problemy gumanitarnykh i yestestvennykh nauk. Zhurnal nauchnykh publikatsiy, 8, pp. 380-385. Institute for Strategic Studies, Moskva.

5. Aliyeva, Y. N., Aliyeva, S. N., Vatandaş, P. (2017). Sociological Analysis of Family Questions in Muslim Society in the Age of Globalization: Regional Characteristics (Based on the Example of Azerbaijan Society). USOS-2017 - 1st International Congress On Social Sciences on September 18-24, 2017 in collaboration with the University of Malaga and "Turkish Studies" Elmi Magazine in Qranada, Spain. (Book of Abstracts - Absrtact Boook). (3 N Publications, Ankara). Malaga, Spain. pp. 222-223.

6. Allakhverdiyeva, I. R. (1994). Sotsial'no-psikhologicheskiy analiz supruzheskogo konflikta v Azerbaydzhanskoy sem'ye [Socio-psychological analysis of the conjugal conflict in the Azerbaijani family]. PhD Thesis, Baku.

7. Dorofeyeva, T. G. (2014). Etika semeynykh otnosheniy v mirovykh religiyakh: monografiya [Ethics of family relations in world religions: monograph]. Penza: RIO PGSKHA, 2014.

Gasanov, R. M. (2003). Formirovaniye grazhdanskogo obshchestva v usloviyakh transformatsii [Formation of a civil society in conditions of transformation]. Baku.

Geybullayev, G. A. (1966). Sovremennaya sem'ya i semeynyy byt azerbaydzhantsev [Modern family and family life of Azerbaijanis]. PhD Thesis, Baku.

8. Mirzajanzade, A. H. (1993). Etyudy o gumanitarizatsii obrazovaniya [Etudes about the humanitarization of education]. Baku.

9. Radayev, V. V., Shkaratan, O. I. (1996). Sotsial'naya stratifikatsiya [Social stratification]. Moscow.

10. Ragimov, A. A., Gasanov, R. M. (2003). Transformatsionnyye protsessy i problema natsional'noy bezopasnosti $v$ Azerbaydzhane [Transformation processes and the problem of national security in Azerbaijan]. Baku.

11. Sadykov, A. I. (1970). Perezhitki semeynoy obshchiny v Vostochnom Azerbaydzhane v kontse XIX nachale XX vekov [Remnants of the family community in East Azerbaijan in the late XIX - early XX centuries]. PhD Thesis, Baku. 
Appendix

QUESTIONARY

Sociological research on the family

(family relations and family education)

Sex:

1. Male 001

2. Female 002

2. Your age:

1. 18-25 years old 003

2. 26-35 years old 004

3. 36-45 years old 005

4. 45-55 years old 006

5. 56-65 years old 007

6. 66 years old and older 008

3. What is your nationality?

1. Azerbaijani 009

2. Other (please specify) 010

4. Education:

1. Elementary (7 classes and below) 011

2. Incomplete secondary ( 9 classes) and (or) professional courses (PTU, Schools of factory apprenticeships, RU without secondary education)

3. Среднее техническое 013

4. General secondary (10,11 classes, lyceum) 014

5. Secondary special (college, technical school, school) 015

6. Incomplete higher education (at least 3 courses) 016

7. Higher education 017

$\begin{array}{ll}\text { 8. Bachelor } & 018\end{array}$

9. Academic degree: Master's degree 019

$\begin{array}{lll}P h D & 019 \mathrm{a}\end{array}$

Doctor of Science 0196

5. Which of the following social categories do you belong to?

1. Intellectuals

2. Entrepreneurs 021

3. Workers 022

4. Peasants 023

5. Students (pupils) 024 
6. Pensioners

7. Housewives

6. Please tell me, are you currently working or studying?

1. I have a permanent job

2. I have a temporary job

3. I combine study with work

4. I study (transition to question number 8)

030

5. I do not work and I do not study (transition to question number 8)

7. Your occupation:

1. Entrepreneur

2. Technical engineer

3. Worker

4. Oilman

5. Teacher

6. Researcher

7. Doctor, health worker

8. Worker of the state apparatus

9. Employee of the banking system

10. Serviceman

11. A law enforcement officer (police, court, prosecutor's office)

12. Employee of administrative bodies

13. Cultural Worker

14. Service worker

15. Employee

16. Agricultural Worker

17. Other (name please)

8. Please determine the significance of the following aspects of your life?

\begin{tabular}{|l|c|c|c|c|c|c|}
\hline \multicolumn{1}{|c|}{ Variants of answers } & 1 place & 2 place & 3 place & 4 place & 5 place & 6 place \\
\hline Good health & 049 & 050 & 051 & 052 & 053 & 054 \\
\hline $\begin{array}{l}\text { Mutual understanding in the } \\
\text { family (with children, parents) }\end{array}$ & 056 & 057 & 058 & 059 & 060 & 061 \\
\hline Getting a good education & 063 & 064 & 065 & 066 & 067 & 068 \\
\hline Successful marriage & 070 & 071 & 072 & 073 & 074 & 075 \\
\hline Material well-being & 077 & 078 & 079 & 080 & 081 & 082 \\
\hline Interesting work & 084 & 085 & 086 & 087 & 088 & 089 \\
\hline Prestigious position in society & 091 & 092 & 093 & 094 & 095 & 096 \\
\hline
\end{tabular}

9. How do you assess the financial situation of your family?

1. High (rich / well fixed)

2. Average (low or unsecured) 
3. Low (poor)

4. Difficult to answer

10. Your marital status:

1. Married

2. Divorced (transition to question \# 13)

3. Not married (not single) (transition to question \# 13)

4. Widower (widow) (transition to question \# 13)

11. Are you satisfied with your marital relationship?

1. Satisfied

2. Satisfied (to a certain extent)

3. Rather not satisfied

4. Not satisfied

Additional questions regarding the aspect of the 11th question:

11(1). How the interpersonal relationships in your family have changed under the current conditions?

1. Relations in the family have not changed

2. Changed for the better

3. Changed for the worse

4. Difficult to answer

11(2). Does your family have a redistribution of duties of spouses at home?

1. Yes

2. No

3. Difficult to answer

11(3). How would you like to divide the duties of spouses at home?

1. Joint distribution of household chores

2. Hard work at home should be performed by men, and help in everything

3. Everyone should have their own duties

4. The wife should lead a housekeeping, and the husband to buy products, to be engaged in children

11(4). Are the different problems discussed jointly (between spouses)?

1. Discuss the household affairs of the family

2. Questions of professional activity

3. Problems of raising children

4. Free time plans

11(5). What is more important for you? (a question for women)

1. Family life 
2. Professional activity

3. Family life and professional activity

12. Please indicate the main causes of marital conflicts in your family: (multiple answers are possible)

1. Accumulated problems

2. Lack of money

3. Household troubles

4. Воспитание детей

5. Character of the spouse

6. Own character

7. What other (please specify)

13. Do you have children?

1. Yes

2. No (transition to question \# 15)

14. Who deals with a child upbringing in your family?

1. Mother

2. Father

3. Senior family members (grandmother, grandfather)

4. Other relatives

5. Who is another (specify)

15. What do you think, what role in the upbringing of the child is played by the following social institutions?

\begin{tabular}{|l|c|c|c|c|}
\hline \multicolumn{1}{|c|}{ Variants of answers } & Play an important role & $\begin{array}{c}\text { Have an insignificant } \\
\text { influence }\end{array}$ & Do not have influence & Difficult to answer \\
\hline Family & 124 & 125 & 126 & 127 \\
\hline Mass media & 128 & 129 & 130 & 131 \\
\hline $\begin{array}{l}\text { Educational } \\
\text { establishments }\end{array}$ & 132 & 133 & 134 & 139 \\
\hline Social environment & 136 & 137 & 138 & 143 \\
\hline What other (specify) & 140 & 141 & 142 & \\
\hline
\end{tabular}

16. In your opinion, on what factors does the effectiveness of family upbringing depend? (several possible answers are possible)

1. Full family

2. Incomplete family

3. Large family

4. Small family

5. Moral and psychological climate in the family

6. Form and nature of communication with children

7. Parent authority

8. Pedagogical culture of parents 
9. What others (please specify)

17. Do you think that parents should provide their child financially until they come of age or until they work?

1. Until adulthood

2. While he does not work

3. What else (please specify)

18. In your opinion, did the changes in the field of culture, science and technology in the world have an impact on the process of educating children in our country?

1. Had a significant impact

2. Had an impact to a certain extent

3. Rather did not have

4. Did not have

5. Difficult to answer

19. How has the relationship in your family changed regarding the aspect of the 18th question?

1. Changed for the better

2. Changed for the worse

3. Relations in the family have not changed

4. Difficult to answer

20. In what direction, in your opinion, is it necessary to educate children in modern conditions?

1. In the spirit of high appreciation of spiritual values

2. According to the requirements of time

3. It is important to take into account both

4. Difficult to answer

21. Should parents provide their child with freedom in his professional orientation?

1. Yes. They should

2. The limitations of this freedom must exist

3. The choice should be made by parents

4. Difficult to answer 